\title{
Cyclin-Dependent Kinase 9
}

National Cancer Institute

\section{Source}

National Cancer Institute. Cyclin-Dependent Kinase 9. NCI Thesaurus. Code C126982.

Cyclin-dependent kinase 9 (372 aa, $\sim 43 \mathrm{kDa}$ ) is encoded by the human CDK9 gene. This protein plays a role in the positive regulation of transcriptional elong ation. 